\title{
LATE SOVIET FILM INDUSTRY: CREATIVITY AND WORK CULTURE
}

\author{
Tomas MITKUS ${ }^{1, *}$, Raimonda STEIBLYTE் ${ }^{2}$ \\ ${ }^{1}$ Department of Graphical Systems, Faculty of Fundamental Sciences, Vilnius Gediminas \\ Technical University, Sauletekio al. 11, LT-10223 Vilnius, Lithuania \\ ${ }^{2}$ Department of Contemporary History, Faculty of History, Vilnius University, Universiteto g. 7, \\ LT-01513 Vilnius, Lithuania
}

Received 26 May 2017; accepted 9 May 2018

\begin{abstract}
In this paper authors analyse work environment in late Soviet period Lithuanian film industry. This study looks at primary sources (session memos, annual reports, professional film union's memos etc.) and analyses what key elements influenced work ethics of Soviet Lithuanian film crew. Findings suggest that censorship, tolerance of low work ethics and strict annual production planning influenced work environment that accepted low film creative value and negative attitude towards administration.
\end{abstract}

Keywords: censorship, creative industries, film industry, history, Lithuania, management.

\section{Introduction}

Lithuania's film industry, as intergal part of creative industries, has grown much over the past three decades after country gained its independence from Soviet Union (SU). Statistical data provided from Lithuanian Film Centre (LFC) (2017) shows that Lithuanian film production for the last five years is steadily increasing its revenue from local box office and frequently receives appraises from international film festivals. Although, just a decade ago Thomas Elsaesser (2005, p. 8) stated that "the gap between Central/Eastern Europe and Western Europe remains as wide as ever". And this is not surprising outcome - filmmakers from Central and Eastern Europe (CEE), although, with the collapse of the SU gain a creative freedom to express themselves in a cinematic way, but lost guaranteed funding from Moscow and theatrical/television markets through the SU, not to mention a new harsh reality in the market, where local filmmakers now had to compete with increasing numbers of foreign films (Mazierska \& Rascaroli, 2003; KEA, Morawetz, 2009; Faraday, 2000).

\footnotetext{
${ }^{\star}$ Corresponding author. E-mail: tomas.mitkus@vgtu.lt
} 
Therefore, it would be understatement to say that Lithuanian filmmakers (LFs) were greatly affected by fifty years of censorship and industry's management under the rule of Communist Party as a Soviet institution with specific ruling and financing system. Furthermore, the fact that Soviet type of filmmaking was forced upon for half of the century and was different in so many ways from the West simply could not leave LFs without some sort of negative effect. Thus, the first few decades after the collapse of SU for CEE in the context of film history was firstly and foremost a period of survival adaptation to the (now global) Western film market.

It is interesting to note, that there are a lot of various theoretical studies of films from Soviet period (SP) - on a subject of propaganda (Taylor, 2006; Dobrenko, 2007; Kenez, 1985), innovation (Mayorov, 2012; Gillespie, 2005; Cavendish, 2004), prominent artists (Petric, 1978; Briley, 1996), genres (Taylor, 1983; Siefert 2017; Sputnitskaia, 2017), styles (Bohlinger, 2014; Bordwell, 1972; Cavendish, 2013) and identity (Merrill, 2012; Bayadyan, 2008; First, 2015), however, there is relatively little attention paid to analyse working conditions that directly affected cinematic cultural and economic results. Furthermore, various problems (results) were identified in post-Soviet region by film industry's researchers but rarely there was an attempt to identify particular factors (causes) that influenced development of a film industry's and its creative labour that followed from the collapse of SU. This article attempts to fill this void in the literature. It investigates Lithuania Film Studio's (LFS) work culture and creative conditions within period of 1975-1987 and in result determines the key factors and conditions that mostly influenced professional world view of generation of filmmakers that are still creatively and pedagogically are active today.

\section{Film industry's situation in Soviet Union}

Although, today Vladimir Lenin's remark, that "of all the arts for us cinema is the most important" (Taylor \& Christie, 1994, p. xiv) is considered somewhat hackneyed it is still the best single sentence that can describe the process and perception of film industry in the SU throughout all of its duration. Interestingly, cinema in SU also was the key provider of leisure activities (Lawton, 1992). Thus, it would be understatement that cinema had very important part in spreading communist propaganda especially in countries, occupied after World War II (WWII). Thus, film industry in SU was used as self-advertising tool for its entire span. Although, it is important to notice that cinema as propaganda's machine was widely used among all the warring nations, and reached its climax during WWII (Elsaesser, 2005). Same goes for the censorship - United States had institution in charge of moving picture censorship as early as 1907 (Grieveson, 2004). Therefore, although film industry in SU had to comply with strict censorship so that cinema would serve as well-oiled propaganda machine, in this sense filmmakers in the SU did not faced unique restrictions to their creative output.

But for the purpose of this paper it is paramount to look closer at the process of censorship in film industry in the SU. It was a cumbersome system of filmmaking where films with "ideological errors" were not permitted to exist (Golovskoy \& Rimberg, 1986, p. 32). First, written scrip was judged by local cinematography committee, institution that controlled production in a particular Soviet Republic's Film Studio. Thus, movie's script firstly 
was reviewed locally and then, if committee approved it, went for the assessment in Moscow (Černeckaitè, 2005). After assessment there were two most common outcomes: (1) request for various changes in order to fit censorship standards or (2) plain rejection. When film was finished one more review by the National Committee of Cinematography was mandatory. Even at this stage movie could go through some mayor changes: some scenes may be cut out or reshot. It is sufficient to state that after all the supervisory process the initial idea and vision of filmmaker and the final cut of the movie could look quite different. And even if script was approved and film was creatively and technically finished, it still sometimes for one or another reason could be forbidden to reach cinema theatres. Finally, it is important to emphasize that Soviet type of censorship was not constrained within filmmaking process. Creatives that would not fully succumb to political authority could have been severely punished (Kaminskaitè-Jančorienè, 2008).

However, authors are not suggesting that all filmmakers in the late SP became willing participants in making cinematic Soviet propaganda. On the contrary - many filmmakers at this point mastered how to create double meaning for their cinematic creations and in result slipped thru the censorship. In other words, filmmakers could construct movie scenes that would look innocent enough to the censorship (at least not to provide a solid reason to forbid), however, local audience would clearly understand the subtle message. That being said, movie output from Soviet film industry clearly shows that in the late SP filmmakers were tranquil with existing system.

\section{Film industry in late Soviet period and independent Lithuania}

It is interesting to notice that Soviet-Lithuanian feature films had a possibility to incorporate national identity in narratives and characters. Thus, up to mid-1960s LFs had some room (within reason) to incorporate their own ideas or motives. And as Rasa Paukštytè (2004) notices LFs became well versed in Aesopian language.

However, situation changed when Soviet film industry became more heavily bureaucratized in the 1970s and implementation of extremely strict censorship followed in film industry (Kaminskaitè-Jančorienè, 2008; Mikonis-Railienė \& Kaminskaitè-Jančorienè, 2015). As well Moscow stated that there will be a new cinematic direction - Soviet working man. Narratives that did not follow this direction (or work theme was not central) would not receive a funding. Thus, this period in film industry was stagnant as many scripts were rejected.

In the last decade of SP (until 1990) Lithuania annually with a little variation in numbers produced seven feature films, 40 documentaries and two animation films (Paukštytè, 2004). Naturally all produced films (including animation and documentary) had to be approved by censorship apparatus. However, this decade came with new challenges. Strict requirement to produce "Soviet reality" narratives resulted in oversupply of work themed films to an audience that after all day of intense labour in factories or workshops wanted to escape from work. Not to mention rise of TV and videocassette recorder usage within population that also greatly influence overall decrease in cinema attendance in Lithuania. Although in the 1980s in SU a new moment that was calling for changes in filmmaking system (to create conditions that would promote more popular films as opposed to ideologically "right" 
ones) got momentum changes in Lithuanian film industry was almost non-existing. As Anna Mikonis-Railienė and Lina Kaminskaitè-Jančorienè (2015, p. 349) noted, the lack of initiative to change obviously flawed system was even addressed publicly stating that those Lithuanian films are provincial, boring, non-attractive and just plainly "about nothing and for nobody".

However, LFC did not have a change to transform into better version of itself, because with the end of the 1980s SU started to tumble down.

After the restoration of Lithuanian independence to national film industry the first decade was a grim. Financing and distribution of national film production was changing to say the least, however the right and ability to exercise creative freedom and distribute overseas provided LFs with opportunities that was impossible for few generations. And this period gave rise to few filmmakers that was appraise internationally. However, LFs for most of three decades did not manage produce films that would lure audience to cinemas. This situation changed for better only recently.

\section{Empirical study}

A two-stage approach was designed to achieve the objectives of the research reported in this paper. Firstly, literature's review was conducted to gather all related information about independent and Lithuanian Soviet film industry in late SP. With special interest to work culture related theme.

Secondly, in order to find key factors that formed and shaped LFs and their perception of professional environment in the period of 1975-1987 an empirical case study was conducted in 2016 November. For this purpose, LFS as the sole institution that was managing Lithuanian Soviet Republic's film industry ${ }^{1}$ (although, under strict supervision by State Committee for Cinematography of SU), were chosen as research object. All primary sources were acquired from Lithuanian Archives of Literature and Art (Vilnius). The documents investigated had to meet the following two criteria in order to be included in the study:

- They need to be compose, or referred to the timeframe of 1975-1987;

- They need to refer to managerial aspects of film creation (work environment, moral code, motivating and demotivating factors, social constructs and etc.) and not related with film narrative or cultural value analysis.

The goal of documents' study was to collect primary sources that recorded discussions of everyday working conditions and specific decision-making aspects of management. For this purpose, authors reviewed files like session memos, annual reports, professional film union's memos etc. Over 40 files that meet the criteria were found and analysed. Official documents produced in LFS institution within the period were analysed and compered with written memoirs and biographies. This was done to get insight to documented LFS reports and to find out how creatives themselves felt about management and working environment. And to understand what work environment effect had to LFS filmmakers.

\footnotetext{
${ }_{1}$ Although there were cases of film production in TV studio, it was spares and most active filmmakers from late SP were LFS alumni.
} 


\section{Literature review}

It is important to identify and explore the nature of working conditions and environment of the only film making place in the state at the late SP. Gathered information could provide insight not only to the filmmaking values and worldview of generation of LFs that are still creatively active today, but also could expand understanding of post-Soviet region struggle to produce cinematic experience that would lure viewers to cinema theatres.

As it was mentioned in introductions there is almost no research done specifically on working conditions and environment in LFS and its possible effect to film industry in independent Lithuania. Although, filmmaking in Lithuania in late SP is to some extend analysed by various authors (Mikonis-Railienè \& Kaminskaitė-Jančorienè, 2015; KaminskaitèJančorienė \& Švedas, 2013; Rakauskaitė, 2010; Tapinas, 2009) almost all works concentrate on administrative and creative part of filmmaking process, creative personalities (stars) and film content analysis.

However, there is a lack of studies that analyse work culture of the period and its effect on development of film industry in the post-Soviet period. Reason to suspect that filmmaking work culture of late SP could have profound impact to film industry performance in postSoviet period is based on Lithuanian film economic accomplishments. Table 1 shows market share of national films in Baltic States in the last decade. It is interesting to note that only in the last few years there is a strong positive change in Lithuanian film industry performance.

Of course, this could be happening because of overall economic growth in Lithuania that led to annually increased direct state aid support to local film industry. This in turn helped to fund not only bigger scale national film projects but also increased their number annually. Positive effect to film industry could also provide Lithuania becoming a full-fledged member of the European Union (EU) in 2004. However, in this scenario positive effect should have been noticeable much sooner not only after a decade of joining EU. Thus, this bring the question why changes happened only recently.

Table 1. Market share of national films production including co-production (Cinema D'Europa MEDIA Salles 2014 (a); UNIC 2015 (b), 2016 (c); Baltic Films: Estonia, Latvia, Lithuania 2006 (d), 2007 (e), 2012 (f), $2017(\mathrm{~g})$

\begin{tabular}{|c|c|c|c|}
\hline & Estonia & Lithuania & Latvia \\
\hline 2005 & $5.1 \%(\mathrm{~d})$ & $6.6 \%(\mathrm{~d})$ & $2.5 \%(\mathrm{~d})$ \\
\hline 2006 & $9.1 \%(\mathrm{e})$ & $4.0 \%(\mathrm{e})$ & $5.7 \%(\mathrm{e})$ \\
\hline 2007 & $14.3 \%(\mathrm{a})$ & $7.7 \%(\mathrm{a})$ & $7.9 \%(\mathrm{a})$ \\
\hline 2008 & $7.3 \%(\mathrm{a})$ & $2.6 \%(\mathrm{a})$ & $1.9 \%(\mathrm{a})$ \\
\hline 2009 & $2.0 \%(\mathrm{a})$ & $1.1 \%(\mathrm{a})$ & $4.3 \%(\mathrm{a})$ \\
\hline 2010 & $2.0 \%(\mathrm{a})$ & $3.2 \%(\mathrm{a})$ & $6.9 \%(\mathrm{a})$ \\
\hline 2011 & $6.9 \%(\mathrm{a})$ & $9.7 \%(\mathrm{a})$ & $4.5 \%(\mathrm{a})$ \\
\hline 2012 & $7.6 \%(\mathrm{~b})$ & $2.5 \%(\mathrm{~b})$ & $4.5 \%(\mathrm{f})$ \\
\hline 2013 & $5.9 \%(\mathrm{c})$ & $16.9 \%(\mathrm{c})$ & $4.6 \%(\mathrm{c})$ \\
\hline 2014 & $4.7 \%(\mathrm{c})$ & $20.2 \%(\mathrm{c})$ & $7.6 \%(\mathrm{c})$ \\
\hline 2015 & $11.3 \%(\mathrm{e})$ & $13.8 \%(\mathrm{e})$ & $3.8 \%(\mathrm{e})$ \\
\hline 2016 & $10.5 \%(\mathrm{~g})$ & $19.5 \%(\mathrm{~g})$ & $7.3 \%(\mathrm{~g})$ \\
\hline
\end{tabular}


The idea that key issue for weak performance of national films in cinemas is related to filmmakers' lack of skills to work in a market based economy is not new. After collapse of SU every single post-Soviet Republic's film industry was on the brink of disappearing. Even in Russia, were situation was considerably better, cases of films that were able to recoup its productions cost was rare exception (Larsen, 2003). It could be argued that the key difference between filmmakers in the SU and those that operated in the West was mainly economical. Although, the level in which the government body in the SU could control and manage creative process should not be overlooked or unrecognized. As George Faraday (2000) points out filmmakers in the SU newer based they creative decisions on market demands. Or in other words, filmmakers in the SU had unprecedented degree of liberty from audience. Thus, for decades filmmakers were concerned only how to please authority, and never the audience. Therefore, it is easy to draw conclusions about what could have brought this effect to post-Soviet film industries. However, it is interesting to notice that this cause and effect relationship is rarely brought up in academic papers. Yet situation is quite the contrary in non-academic platforms. Ruthless Lithuanian film critic Edvinas Pukšta (2009, 2010, 2013) is a most noticeable spokesman who is stating that national film industry has ongoing problems. His review of the Lithuanian film industry, emailed to Lithuanian film producers in 2013, managed to provoke tremendous anger of the older LFs' generation (Sagaityte, 2013). An extract from Pukšta’s letter, in his opinion, briefly summarizes the main problems of the film industry:

\begin{abstract}
"They [filmmakers] are flushing taxpayer money down the drain and trying to pass incomprehensible nonsense off to folks, nonsense that is only useful for themselves: films do not need to be viewed, cinema does not even have to have results as a goal, movies do not need to be promoted or advertised; it is enough to show them to your friends. I would like to see such individuals try to make a living and compete in any other country in the world where results are what matter, where you have to account for the state's money you spent, and nobody gets paid just for his name and merits of times past. I have no doubt that Lithuanian cinema will remain alive only when it is watchable, noticeable, visible, and valued primarily by tickets people are willing to pay for" (Sagaityte, 2013).
\end{abstract}

In other words, Pukšta is claiming that the older generation filmmakers are masquerading their inability to create films that would be interesting to the audience by calling it high art. However, this paper will not try to argue nor that filmmakers of late SP generation lack fundamental skills to create compelling movies, nor that they achieved everything that is possible given economic, technical or social circumstances. However, the fact that every single post-Soviet film industry suffered after collapse of the SU and it took decades to recover shows that the key damage to film industry was done on a managerial level, rather than creative. Although, the factor of economic turmoil after the collapse of SU must be acknowledged - raging inflation and video piracy elevated the crisis for film industries in the region in the 1990s (Gorp, 2011). Thus, economically difficult times at the beginning of independence can justify the short period of cinematic drought but not all three decades.

Thus, this research is important to identify what exact factors influenced formation of independent Lithuania's film industry at its dawn. The effects of these problems are fading away as new generation of filmmakers are taking ground. However, insight in to working 
environment that formed this generation of filmmakers across whole region will also enable the identification of avoidable management practice decisions in filmmaking.

\section{Review of archives documents}

Documents from LFS from the period of 1970s and 1980s revealed that working environment in Soviet Lithuanian film industry was negative, designed above all to fulfil formal requirements of film production plans, rather than stimulate creativity.

Data concerning the factor of constant lack of quality equipment were overwhelming. Even post-production process was an issue (Lithuanian Film Studio, 1975). It is interesting to note that reports contain some anecdotal solutions to tackle this problem - authors come across a suggestion to repaint all film cameras to create a feeling of renewal (Professional Film Union, 1975b). This demoralizing situation about lack of quality equipment also heavily refereed in various memoirs and biographies.

Research also indicates that LFS was lacking not only technical equipment but also qualified creative labour. It is important to notice that reports constantly indicated that Lithuanian film community believed that there is a lack of various types of assistants in order to execute film production effectively and to reach production goals. This lack of assistants had side effect that resulted in a low-quality equipment installation and affected quality of set decoration. The issues about the lack of qualified creative labour reappear in reports through all period (Lithuanian Film Studio, 1975a, 1975b, 1981).

Reports provided very interesting insight about drinking, absenteeism, and safety violations. Although, information about frequent cases of drinking on set or within institution territory is relatively known fact during that period, this research revealed data about social construct within Soviet Lithuanian film industry regarding alcoholism and problems resulting from this vice. In professional film union's memo (Lithuanian Film Studio, 1978b) it was stated that drinking was very common cause of work related penalties. Thus, there were a lot of efforts put into defeating this habit. Most common measures were disciplinary penalty, public lectures, and public shaming.

It is important to notice, that alcoholism was not an isolated problem. It resulted in noticeable absenteeism and to some extend - lack of work safety. Although, workers complained that the latter was due to the lack of work safety equipment and overall bad working conditions (Lithuanian Film Studio, 1978a). Also, it is important to notice, that not all of drinking cases were documented in reports. Therefore, the real drinking scope in LFS could be considerably bigger.

Evidence indicates that there was a restriction from employing strict punishment for work related violations like alcoholism and/or absenteeism. Evidence also indicates that work position replacement was often implemented instead of firing (Professional Film Union, 1975a, 1978; Lithuanian Film Studio, 1978, 1981, 1982). Furthermore, data revealed that administration was taking care of elder, sick, lonely persons by saving their workplace (Lithuanian Film Studio, 1981, 1985).

Another crucial problem in LFS was a lack of qualified manpower. This lack of qualified manpower can be in part explained by disproportional distribution of film production over 
a period of a year. All film crew were paid only during film production. Therefore, in winter, when the volume of film productions is usually smaller, part of film community may end up without any income for considerable duration. This unpleasant situation for filmmakers was addressed few times and, in result, additional work was allowed in other cultural institutions (most often in television) (Collective Agreement, 1982). Thus, frequent employees' turnover was common.

Finally, a great deal of filmmaking process was affected by constant and intrusive supervision from LFS administration. Reports show that this situation resulted from attempt to meet annual plans, approved by the Central Committee and Communist Party. Reports suggest that it occasionally resulted in erratic work, hasty production. There was regular demand to reconsider deadlines, which in turn resulted in additional production costs (Professional Film Union, 1975b, 1978). This situation of administration invasion to creative process is widely documented in memoirs and literature (Kaminskaitè-Jančorienè \& Švedas, 2013; Tapinas, 2009; Mikonis-Railienè \& Kaminskaitė-Jančorienė, 2015; Rakauskaitė, 2010).

\section{Discussions}

Authors identified 4 key factors that greatly affected LFs and their perception of professionalism and work ethics in late SP. These 4 factors are:

- Constant lack of quality equipment;

- Qualified manpower;

- Drinking, absenteeism, and safety violations were common;

- Strict supervision in every stage of filmmaking process.

It is hard to see direct link between work environment of late SP in LFS and inability to lure national audience to cinema theatres for few decades. And most likely there is none, at least not direct one. Study indicates that for decades work environment was toxic for more than one reason. And that in turn formed a work culture in LFS of conformism. Even today many creative profile companies facing challenges rising from conformism among teams that had to create or innovate (Miron-Spektor, Erez, M., \& Naveh, 2011). Thus, is not surprising that this outcome would happen in totalitarian regime.

In this paper authors define conformism as a set of believes and values of a person that conforms to the usual practices or standards of a group, society, etc. In the context of LSF of the late SP that means that filmmakers were prone to follow rules and even resistance to change. In other words, they tend to generate ideas that are more likely to be accepted by their group and organization (Goncalo \& Staw, 2006; Miron, Erez, \& Naveh, 2004). However, it is important to notice, that the SU had complete monopoly over filmmaking in given period and in given space. Therefore, there were no other options for filmmakers. Thus, one should not simplify the situation that creative people had to experience in SU.

Still, because social construct for creatives in Soviet film industry was quite simple economic income and prestige (in this context - perks rather than admiration for creating propaganda type films) for the "right movies" or economic drought and creative banishment for the "wrong movies", motivation to receive approval of controlling institutions was naturally high. As well failure to comply with the authorities was punishable. Sometimes final 
product was not acceptable and "it went on the shelf" (Kaminskaitė-Jančorienè \& Švedas, 2013). Although, this radical decision to prohibit distribution of a finished movie was officially justified by labeling it as "poor quality" movie, the harsh reality was that sometimes it was just a way to deal with film directors who were somehow not acceptable to the regime. Thus, filmmakers were economically interested to make "ideologically right" movies.

Another important work environment element that needs to be discussed is LFS supervision in every stage of filmmaking process. Evidence and memoirs suggest that system of management was ineffective and rigid. Technically LFS purpose of this strict supervision was to insure, that not only limited recourses were used according the plan, but also that narratives were always fallowing Moscow thematic directions. But as Mikonis-Railienè and KaminskaitéJančorienè (2015) noticed in late SP most of LFS administration was not competent with filmmaking process and thus usually were just following directions from Moscow to the letter.

Thus, although conformism was forced upon filmmakers, conflicts in LFS were extremely common. As Mikonis-Railienė and Kaminskaitė-Jančoriené argue (2015, p. 345) “it looks like everybody was in a conflict with everyone: directors with scriptwriters, camera operators with directors, directors again with administration etc.". Thus, work environment was filled with mistrust and disunity.

This led to ongoing filmmakers' unwillingness to listen instructions of how to create a film. Or even how to administrate funding received through direct state aid. For example, LFS alumni animator Ilja Bereznickas (2017, p. 51) in his resent textbook for future animators gives this advice: "If there are any questions about these things [creative process for animation] act so that artistic part of the film would not suffer. Do not give in to the requirements of amateur and bureaucrats. Fight and you will win. After all, an auteur's film has to stay auteur's film [...]".

Similar sentiments were publicly proclaimed by internationally acknowledged filmmakers Algimantas Puipa (Žižliauskaitė, 2011) and Šarūnas Bartas (Brašiškis, 2009). Thus, the quote illustrates generation's distrust towards any type of management interference. Be that from government investor or private. Therefore, authors will argue that for decades toxic environment present in LFS shaped and formed filmmakers so that their (to a various degree) want to (a) control film's creative process (outside traditional directors position) and (b) distrust (even despise) any type of supervision. With the goal for them to recognized as an auteurs. These sets of principals, of course, do allow creating cinematic masterpieces that would be acclaimed internationally within Cine-Files. However, this is not a recipe to lure audience to the cinema theatres.

At the end of the 1980s filmmakers were a product of a system that stimulated obedience above all. Meanwhile creativity and artistic innovation were tolerated as long they were used to provide "ideology correct" message. Thus, Faraday (2000) argues that it was filmmakers themselves that brought decline to their industry after collapse of the SU - they were not able to make films based on market's demand and this led to instant demise of film industries in post-Soviet states. Five decades of filmmaking system that forced to ignore any demand from cinema viewers and encouraged only to developed skills to develop "right" film projects in order to get funded could not simply be replaced overnight. And the drive to create unsupervised and unchallenged cinematic product can be damaging. 


\section{Conclusions}

As evidence shows creative and administrative work conditions in Soviet film industry were often tough. Authors identified 4 key aspects of LF's professional environment. These 4 aspects were: (a) constant lack of quality equipment and (b) qualified manpower, (c) noticeable drinking, absenteeism, and safety violation problems, and (d) strict supervision in every stage of filmmaking process. Although, working conditions were difficult, administration practiced protectionism for non-political work violations. This created an image of "safe workplace". However, all these factors let to formation of conformism among filmmakers.

This study has implications for local and regional film history and for cultural policymakers. First, this study provides empirical evidence about the context of working conditions for LFs who operated in late SP and how they effected the perception of professionalism and work ethics. Furthermore, study provides context and insights for the demise of post-Soviet film industries in the region. Second, evidence suggests that high ignorance that filmmakers posse to film audience desires is a result of a Soviet filmmaking system.

It is important to note limitations of this study. Authors focused solely on Lithuania's film industry. Therefore, researchers and policy-makers should be cautious when generalizing and adapting results to other countries and/or creative industries segments. Authors, thus, suggest that this study would be expanded to other post-Soviet countries and creative segments as a way to validate universality of the results.

\section{References}

Baltic Films: Estonia, Latvia, Lithuania. (2006). Facts \& Figures. Retrieved from http://filmi.ee/wordpress/wp-content/uploads/2014/11/Facts_Figures-2006.pdf

Baltic Films: Estonia, Latvia, Lithuania. (2007). Facts \& Figures. Retrieved from http://filmi.ee/wordpress/wp-content/uploads/2014/11/Facts_Figures-2007.pdf

Baltic Films: Estonia, Latvia, Lithuania. (2012). Facts \& Figures. Retrieved from http://www.lkc.lt/wp-content/uploads/2013/02/FF-2013.pdf

Baltic Films: Estonia, Latvia, Lithuania. (2017). Facts \& Figures. Retrieved from http://nkc.gov.lv/en/wp-content/uploads/sites/2/2014/09/FF-2017-web.pdf

Bayadyan, H. (2008). Soviet Armenian identity and cultural representation. In T. Darieva \& W. Kaschuba (Eds.). Representations on the Margins of Europe: Politics and identities in the Baltic and South Caucasian States. Frankfurt/New York: Campus Verlag, 205-219.

Bereznickas, I. (2017). Animacija: Nuo idejos iki ekrano. Vilnius: Vilniaus dailès akademijos leidykla.

Bohlinger, V. (2014). Book review of Philip Cavendish's the men with the movie camera: The poetics of visual style in Soviet Avant-Garde cinema of the 1920s. Studies in Russian and Soviet Cinema, 8(3), 236-238. https://doi.org/10.1080/17503132.2014.969915

Bordwell, D. (1972). The idea of montage in Soviet art and film. Cinema Journal, 11(2), 9-17. https://doi.org/10.2307/1225046

Brašiškis, L. (2009). Šarūnas Bartas - lietuvių kino filosofas. Bernardinai.lt. Retrieved from http://www.bernardinai.lt/straipsnis/2009-11-04-sarunas-bartas-lietuviu-kino-filosofas/34707

Briley, R. (1996). Sergei Eisenstein: The Artist in service of the revolution. The History Teacher, 29(4), 525-536. https://doi.org/10.2307/494802 
Cavendish, Ph. (2004). Book review of David Gillespie's early Soviet cinema: Innovation, ideology and propaganda. The Modern Language Review, 99(1), 273-274. https://doi.org/10.2307/3738974

Cavendish, Ph. (2013). The men with the movie camera: The poetics of visual style in Soviet Avant-Garde cinema of the 1920s. New York: Berghahn Books.

Černeckaitè, I. (2005). Sovietinè kino dokumentika Lietuvoje: istoriniai ir ideologiniai kontekstai (1963-1988 m.). Genocidas ir rezistencija, 1(17), 35-50.

Cinema D’Europa MEDIA Salles. (2014). 2013: European cinema yearbook. Retrieved from http://www.mediasalles.it/ybk2013/index.html

Collective Agreement. (1982). Collective agreement. Vilnius: Lithuanian Film Studio.

Dobrenko, E. (2007). Creation myth and myth creation in Stalinist cinema. Studies in Russian and Soviet Cinema, 1(3), 239-264. https://doi.org/10.1386/srsc.1.3.239_1

Elsaesser, Th. (2005). European cinema: Face to face with Hollywood. Series: Film Culture in Transition. Amsterdam: Amsterdam University Press. https://doi.org/10.5117/9789053566022

Faraday, G. (2000). Revolt of the filmmakers: The struggle for artistic autonomy and the fall of the Soviet film industry. Pennsylvania: The Pennsylvania State University Press.

First, J. (2015). Ukrainian cinema: Belonging and identity during the Soviet Thaw. Series: KINO: The Russian and Soviet Cinema Series. R. Taylor (Series Ed.). London, New York: I.B. Tauris \& Co Ltd.

Gillespie, D. (2005). Early Soviet cinema: Innovation, ideology and propaganda. London and New York: Wallflower.

Golovskoy, V. S., \& Rimberg, J. (1986). Behind the Soviet screen. The motion picture industry in the USSR, 1972-1982. Michigan: Ardis Publishers.

Goncalo, J. A., \& Staw, B. M. (2006). Individualism-collectivism and group creativity. Organizational Behavior and Human Decision Processes, 100(1), 96-109. https://doi.org/10.1016/j.obhdp.2005.11.003

Gorp, Van J. (2011). Inverting film policy: Film as nation builder in Post-Soviet Russia, 1991-2005. Media, Culture \& Society, 33(2), 243-258. https://doi.org/10.1177/0163443710393384

Grieveson, L. (2004). Policing cinema: Movies and censorship in Early-Twentieth-Century America. Berkeley, Los Angeles, London: University of California Press.

Kaminskaitė-Jančorienė, L. (2008). „Brežnevinio sąstingio“ praeities deformacijos lietuviškuose kino ir televizijos vaidybiniuose filmuose (1968-1980 metai). Lietuvos istorijos studijos, 22, 104-116.

Kaminskaitė-Jančorienė, L. ir Švedas, A. (2013). Epizodai paskutiniam filmui. Režisierius Almantas Grikevičius. Vilnius: Vaga.

KEA; Morawetz, N. (2009). The impact on the impact of European support programmes on the State of Lithuanian audiovisual industries. Retrieved from http://www.keanet.eu/wp-content/uploads/ Final-Report-Lithuania-Executive-Summary.pdf

Kenez, P. (1985). The birth of the propaganda State: Soviet methods of mass mobilization, 1917-1929. Cambridge: Cambridge University Press. https://doi.org/10.1017/CBO9780511572623

Larsen, S. (2003). National identity, cultural authority, and the post-soviet Blockbuster: Nikita Mikhalkov and Aleksei Balabanov. Slavic Review, 62(3), 491-511.https://doi.org/10.2307/3185803

Lawton, A. (1992). Kinoglasnost: Soviet Cinema in our Time. Series: Cambridge Soviet Paperbacks. Cambridge: Cambridge University Press.

Lithuanian Film Center. (2017). Lithuanian Film Center. Retrieved from http://www.lkc.lt/en/

Mayorov, N. (2012). A First in Cinema... Stereoscopic Films in Russia and the Soviet Union. Studies in Russian and Soviet Cinema, 6(2), 217-239. https://doi.org/10.1386/srsc.6.2.217_1

Mazierska, E., \& Rascaroli, L. (2003). From Moscow to Madrid: postmodern cities, European cinema. London, New York: I.B. Tauris. 
Merrill, J. (2012). Brothers and others: Brotherhood, the Caucasus, and National Identity in Post-Soviet Film. Studies in Russian and Soviet Cinema, 6(1), 93-111. https://doi.org/10.1386/srsc.6.1.93_1

Mikonis-Railiene, A. ir Kaminskaitė-Jančorienè, L. (2015). Kinas sovietų Lietuvoje: sistema, filmai, režisieriai. Vilnius: Vilniaus dailès akademijos leidykla.

Miron, E., Erez, M., \& Naveh, E. (2004). Do Personal Characteristics and Cultural Values that Promote Innovation, Quality, and Efficiency Compete or Complement Each Other?. Journal of Organizational Behavior 25(2), 175-199. https://doi.org/10.1002/job.237

Miron-Spektor, E., Erez, M., \& Naveh, E. (2011). The effect of conformist and attentive-to-detail members on team innovation: Reconciling the innovation paradox. The Academy of Management Journal, 54(4), 740-760. https://doi.org/10.5465/amj.2011.64870100

Paukštytè, R. (2004). Lithuanian cinema in 1990-2004. Lithuanian Film Center. Retrieved from http://www.lfc.lt/en/Page=ArticleList\&ID=1118\&Y=2004

Petric, V. (1978). Dziga Vertov as Theorist. Cinema Journal, 18(1), 29-44. https://doi.org/10.2307/1225210

Professional Film Union. (1975a). Meeting of committee of professional film union protocol. Vilnius. Lithuanian Film Studio.

Professional Film Union. (1975b). Protocols, reports and plans of permanent Committee of Professional Film Union. Vilnius: Lithuanian Film Studio.

Professional Film Union. (1978). Annual plans and reports of Committee of Professional Film Union. Vilnius: Lithuanian Film Studio.

Lithuanian Film Studio. (1975a). Protocols of Committee of Professional Film Union Sessions. Protocols. Vilnius.

Lithuanian Film Studio. (1981). Protocols of Committee of Professional Film Union Sessions. Protocols. Vilnius.

Lithuanian Film Studio. (1982). Protocols of Committee of Professional Film Union Sessions. Protocols. Vilnius.

Lithuanian Film Studio. (1985). Protocols of Committee of Professional Film Union Sessions. Protocols. Vilnius.

Lithuanian Film Studio. (1975b). Annual statistical reports of Committee of Professional Film Union. Reports. Vilnius.

Lithuanian Film Studio. (1978a). Reports and plans on creative employees and workers in training. Reports. Vilnius.

Lithuanian Film Studio. (1978b). Report about the Lithuanian Film Studio's ongoing Work on the Legal and Moral Education and Fight with Alcoholism. Reports. Vilnius.

Pukšta, E. (2009). Edvinas Pukšta: „Aš asmeniškai nesuprantu, kam tokie filmai kaip ,Duburys` ir ,Perpetuum mobile‘ yra reikalingi. Obuolys. Retrieved from Internet www.obuolys.lt/labas/naujiena/8041/

Pukšta, E. (2010). Lietuvos žvaigždès užgesta užburtame kino rate. Valstybe், 12(44), 122-125.

Pukšta, E. (2013). Lietuvių kino renesansas pažers rekordinị filmų derlių. Delfi pramogos. Retrieved from www.delfi.lt/pramogos/kinas/e-puksta-lietuviu-kino-renesansas-pazers-rekordini-filmuderliu.d?id=61466028

Rakauskaite, R. (2010). Šoblè: atsiminimai apie dokumentinio kino klasikq Henrika Šablevičių. Vilnius: Dominicus Lituanus.

Reports. (1975). Annual statistical reports of Committee of Professional Film Union. Vilnius: Lithuanian Film Studio.

Reports. (1978a). Reports and plans on creative employees and workers in training. Vilnius: Lithuanian Film Studio. 
Reports. (1978b). Report about the Lithuanian Film Studio's ongoing Work on the Legal and Moral Education and Fight with Alcoholism. Vilnius: Lithuanian Film Studio.

Sagaitytè, B. (2013). E. Pukštos nuomonè apie kino padètị Lietuvoje įsiutino kino kūrẻjus. Delfi pramogos. Retrieved from www.delfi.lt/pramogos/kinas/epukstos-nuomone-apie-kino-padeti-lietuvojeisiutino-kino-kurejus.d?id=60373585\#ixzz3N5gv4lmy

Siefert, M. (2017). Film and television genres of the late Soviet era: Book review. Studies in Russian and Soviet Cinema, 11(3), 264-265. https://doi.org/10.1080/17503132.2017.1366062

Sputnitskaia, N. (2017). The Politics of Outer Space: Colonisers and Missionaries in Russian Fantasy Film of the 1930s, Studies in Russian and Soviet Cinema 11(2): 134-145. https://doi.org/10.1080/1 7503132.2017.1300426

Tapinas, L. (2009). Laiškanešys, pasiklydęs dykumoje. Vytauto Žalakevičiaus gyvenimo ir kūrybos pèdsakais. Vilnius: Alma littera.

Taylor, R. (1983). A "Cinema for the Millions": Soviet socialist realism and the problem of film comedy. Journal of Contemporary History, 18(3), 439-461. https://doi.org/10.1177/002200948301800305

Taylor, R. (2006). Film propaganda: Soviet Russia and Nazi Germany. Series: KINO: The Russian and Soviet cinema series. R. Taylor (Series Ed.). London, New York: I.B. Tauris \& Co Ltd.

Taylor, R., \& Christie, I. (Eds.). (1994). The film factory: Russian and Soviet cinema in documents, 1896-1939. London, New York: Routledge.

UNIC. (2015). UNIC Annual Report 2013-2014. Brussels: International Union of Cinemas.

UNIC. (2016). UNIC Annual Report 2014-2015. Brussels: International Union of Cinemas.

Žižliauskaite, L. (2011). Algimantas Puipa: „Jei susėsčiau su rašytojais, jausčiausi kaip per Niurnbergo procesą“. Bernardinai.lt. Retrieved from http://www.bernardinai.lt/straipsnis/2011-06-29-algimantas-puipa-jei-susesciau-su-rasytojais-jausciausi-kaip-per-niurnbergo-procesa/65151

\title{
VÉLYVOJO SOVIETINIO LAIKOTARPIO KINO INDUSTRIJA: KŪRYBIŠKUMAS IR DARBO KULTŪRA
}

\author{
Tomas MITKUS, Raimonda STEIBLYTE் \\ Santrauka
}

Šiame straipsnyje autoriai analizuoja Lietuvos kino industrijos darbo aplinką vèlyvuoju sovietiniu laikotarpiu. Siekiant identifikuoti pagrindines priežastis, kurios lèmé sovietmečio kūrybinès kino komandos darbo etikos susiformavimą, straipsnyje apžvelgiami pirminiai šaltiniai: posėdžių protokolai, metinès ataskaitos, kino studijos profesinès sąjungos protokolai. Duomenys rodo, kad cenzūra, žemos darbo etikos toleravimas ir griežtas metinès produkcijos planavimas buvo pagrindinès priežastys, lèmusios kino kūrẻjų darbo kultūrą, kuri suformavo toleranciją žemos kūrybinès vertès kino produkcijai bei neigiamą požiūrị ị administracinị personalą.

Reikšminiai žodžiai: cenzūra, kūrybinès industrijos, kino industrija, istorija, Lietuva, vadyba. 